\title{
SOCIO-DEMOGRAPHIC CHARACTERISTICS AS INFLUENCE FACTORS ON THE COMPLAINANT'S LOYALTY - THE TRAVEL AGENCIES OF SERBIA AND CROATIA
}

\author{
Jelena Jevtić57 \\ Ksenija Leković 58 \\ Slavica Tomić, ${ }^{59}$
}

https://doi.org/10.31410/itema.2018.142

\begin{abstract}
Failures are inevitable, especially in service companies where production and consumption take place simultaneously, and the human factor participation is dominant. In addition to knowing factors of influence to the loyalty of satisfied users, it is necessary to determine the existence and influence of factors on the retention of dissatisfied users. The research presented in the paper is based on determining the differences in the complainant's loyalty regarding their socio-demographic characteristics. Therefore, the research subject is the impact that socio-demographic characteristics have on the complainant's loyalty to travel agencies from Serbia and Croatia. The aim of the research is to determine the statistically significant differences to the complainant's loyalty in relation to the user's socio-demographic characteristics. The empirical part of the research was carried out by a survey technique. The results of the conducted empirical research confirmed the findings and claims of foreign authors regarding the place of residence and the impact of the service users' monthly income to the loyalty to a specific travel agency. The purpose of this paper is to point out the possibility of using complaints and service recovery in order to build better and long-term relationships with the users of travel agency services. The obtained results may indicate to travel agencies the importance of knowing their service users' profile. By disposing with a unique user database, a specific travel agency creates the preconditions needed for quick measures and actions in situations of user dissatisfaction.
\end{abstract}

Keywords: travel agencies, complaints, loyalty, socio-demographic characteristics

\section{INTRODUCTION}

A travel agency operates as a forwarding company or only produces services that meet the needs of its users while temporarily changing their place of residence, or by organizing a trip [1]. Since tourism products are complex (consisting of a large number of different products and services), users are not passive recipients; rather, they are more of employees with half the work that actively influence the attitudes and behavior of employees. Users and employees are an integral part of a service company and they create values more efficiently and effectively through knowledge, understanding and trust [2]. The main task of a travel agency is to deliver superior value to its users. The prerequisite for delivering superior value is maintaining quality relationships with customers. A travel agency should develop a strategy that maintains a stable portfolio of users over time if it wants to stay on the market in the long run [3]. Despite the importance of travel agencies in tourism distribution, little attention

\footnotetext{
${ }^{57}$ High Medical and Business Technology College of Vocational Studies, Šabac, Serbia

${ }^{58}$ University of Novi Sad, Faculty of Economics, Subotica, Serbia

${ }^{59}$ University of Novi Sad, Faculty of Economics, Subotica, Serbia
} 
has been paid to new challenges and possible success strategies to increase loyalty to travel agencies [4].

As mistakes are an inevitable consequence of human activities, so will the travel agency with the best management have at least one of ten users who will not be satisfied with the service it receives. The process of managing user complaints is being increasingly mentioned as an important precondition for the application of marketing relations in tourism (Alvarez, et al., 2011; Swanson, Hsu, 2011). Some authors point out that if current users are the most productive source of additional or re-engagement, the users lost are likely to be the second best source of additional business [5]. Companies should raise users' awareness about the importance of appeals for providing enhanced services. Proactive encouragement of complaints reminds users that their complaints are desirable [6].

On the other hand, an unhappy user is a "potential bomb" full with negative comments and emotions. Their explosion could seriously damage the reputation of the company. Research has shown that users will tell their five closest acquaintances about the manner in which their complaint is handled, but if users receives a good service at the beginning, they will only inform three [7]. Therefore, it is necessary that travel agencies and their travel agents recognize critical situations and undertake emergency actions to solve problems [8]. The actual importance of quality handling of complaints cannot be the same for every company. Some authors state that access to complaints varies depending on the characteristics of users and complaint situations that a company faces. The severity of the problem relates to the degree of economic or noneconomic loss that the user considers to be the result of a service error for him/her. Attributing the responsibility to the travel agency refers to the extent to which the user considers that the cause of the problem is the agency and not him/her and that therefore the particular travel agency is responsible for his/her dissatisfaction. Differences in perceiving the severity of problem and assigning responsibility can result from different psychographic and sociodemographic characteristics of users [9].

Failure to meet customer expectations i.e. unfavorable experience, results in user dissatisfaction [10]. Service providers need to understand the negative comments and emotional aspects of their users are detrimental to the image of a specific travel agency. Lack of understanding of service users disturbs this relationship. In their research some authors come to a conclusion that recovery after a complaint process is equally if not more important than providing a good service at the beginning. It is pointed out that it is of utmost importance in the process of service recovery that users have the means by which they can express their dissatisfaction [7]. The focus of this paper will be on the loyalty of complainants - users of tourist agency services in Serbia and Croatia.

Early researches on service processes focused more on employees and factors influencing the user's tendency to lodge a complaint. However, in this paper, attention is focused on understanding the behavior of users after the service recovery and their subsequent postpurchase decisions. The objective and the problem of the research is the influence that the sociodemographic characteristics have on the loyalty of complainants to tourist agencies from Serbia and Croatia. As neighboring countries, Serbia and Croatia have intertwined cultural and historical heritage. However, the results of the conducted research have shown that some factors affecting the loyalty of complainants, i.e. tourist services users of these two countries, differ. Thus this paper points to the need to know the data about factors that influence loyalty of users after the service recovery process as a prerequisite for knowing the profile of users of that 
particular travel agency. By disposing of a unique database of users, a travel agency creates preconditions needed for quick measures and actions in situations of user dissatisfaction.

\section{REVIEW OF LITERATURE}

The tendency to appeal is the tendency of the user to complain. In research dealing with postconsumer behavior or user behavior, the determinants of the impact on the disadvantage of the disadvantaged users to complain are the demographic and socioeconomic characteristics of the user. According to individual authors, the inclination to appeal includes personality, attitudes and lifestyles as variables that affect the user's tendency to complain when dissatisfied. The socio-demographic characteristics of the user include age, gender, average income, education, place of residence [9]. Different user characteristics are variables which were used to determine the existence of differences in user's complaint behavior [11].

According to the results determined by Heung, V. C. S. and Lam, T. (2003), female users are more involved in the complaint process, and they convey to others their satisfaction or dissatisfaction with how their complaints are handled. Women, young and highly educated users tend to complain more. Young and middle age groups are more involved in complaints than older age groups [12].

Reynolds, K. L., and Harris, L. C. (2005) conclude that users, who are typically younger, highly educated, earn above average income, do a professional job, have women and have children [13].

Tronvoll, B. (2007) states that younger users are more likely to complain, while disgruntled low-income users are insufficiently represented among those who complain [14].

Phau, I. and Baird, M. (2008) found that respondents aged 40 or above expect more from products and services compared to other age groups. According to this research, respondents aged 54 or above potentially have more free time than those who are younger and are therefore willing to spend more time and invest more effort in making a complaint. The results of the research conducted by these authors show that respondents with some type of higher level education have less chances to complain than users with lower education level. Phau, I. and Baird, M. (2008) came to the conclusion that there is no link between income and different levels of complaint behavior [15].

The results of the research conducted by Homburg, C., Fürst, A., and Koschate N. (2010) show that women, as users of services, devote more attention to user service issues, unlike men. These authors come to the conclusion that older users create a need for the company to provide a fair treatment for handling their complaint process. Also, with regard to user's education level, the results of the research support the assumption that users having higher education are able to evaluate the handling of complaints by a company and its outcome is better than those with lower levels of education [9].

The work of the authors Metehan, T. and Yasemin, Z.A. (2011) points out that users older than 40 start to expect more from the services they purchase, and also they do not have much interest in terms of social expectations and perceptions, so therefore they are more prone to complain. Also, respondents older than 54 may have more time available than those who are younger and are therefore willing to spend more time and invest more effort to file a complaint. In the study by these authors, education is another variable, the influence of which on the complaint 
behavior is questioned. A high education level is treated as a demographic variable that can be linked to a greater propensity of the user to lodge a complaint, notify injustice and form higher expectations of the services. The results also show that users with higher income buy more, and therefore can be expected to complain more. The assumption is that individual users with higher incomes have greater personal resources that allow them to express their dissatisfaction more easily [11].

Based on the literature review, it can be concluded that there is no compliance in terms of interpreting the impact of particular user characteristics. A database of permanent, loyal users is a key resource for survival of a company. Therefore, employees need to improve and strengthen their contacts with users. It is important to keep users focused on achieving consistent levels of loyalty and, consequently, of profitability. Since failures are inevitable, it is necessary to provide adequate service recovery and win back the loyalty of users who have filed a complaint in response to unsatisfactory values provided by a particular company. The prerequisite for ensuring the loyalty of previously dissatisfied users is to have information about them. In order to implement an adequate service recovery program, it is necessary to have a database of currently dissatisfied, and then loyal users.

\section{METHODOLOGY OF RESEARCH}

This paper analyzes the impact of socio-demographic characteristics of users - complainants, on their loyalty to travel agencies. The conducted research aims to establish a statistically significant difference in the loyalty of complainants with respect to their socio-demographic characteristics (gender, age, monthly income and residence). The starting point for the realization of this goal is to conduct research and collect data. The research was conducted in Serbia and Croatia in the form of structured testing through a questionnaire distributed online. A questionnaire consisting of two parts was composed based on the review of the relevant literature (Homburg, Furst \& Koschate, 2010; Mattila, 2001; Karatepe, 2006). Questions related to the socio-demographic characteristics of the user (gender, age, monthly income and residence) are included in the first part of the questionnaire. The second part of the questionnaire deals with the loyalty of the complainant. Respondents responded to the statements offered in the second part of the questionnaire by giving grades 1 to 5 (1 - I completely disagree, 5 - I completely agree).

Starting from the main topic as well as research goals of this paper, and taking into account the previous research on this topic, the main hypothesis - that will be the subject to testing with the intention of proving it - is as follows:

\section{$H_{0}:$ There is a statistically significant difference in the loyalty of complainants among tourist services users of various socio-demographic characteristics.}

The set hypothesis $\mathrm{H}_{0}$ is broken down into the following four, auxiliary hypotheses:

$\mathrm{H}_{1}$ : There is a statistically significant difference in the loyalty of complainants among users of the different types of tourist services

$\mathrm{H}_{2}$ : There is a statistically significant difference in the loyalty of complainants between users of tourist services of different ages

$\mathrm{H}_{3}$ : There is a statistically significant difference in the loyalty of complainants among tourist services users of different amounts of monthly income

$\mathrm{H}_{4}$ : There is a statistically significant difference in the loyalty of complainants between tourist service users with different place of residence. 
The survey was conducted in Serbia and Croatia between September 2016 and January 2017, covering 116 respondents from Serbia and 106 respondents from Croatia. Table 1 shows the description of the sample, separately for Serbia and separately for Croatia.

Table 1: Description of the sample of respondents from Serbia and Croatia

\begin{tabular}{|c|c|c|c|c|c|c|}
\hline \multirow{2}{*}{\multicolumn{2}{|c|}{ VARIABLE }} & \multicolumn{2}{|c|}{$\begin{array}{l}\text { SERBIA } \\
\end{array}$} & \multicolumn{3}{|c|}{ CROATIA } \\
\hline & & \multirow{2}{*}{$\begin{array}{c}\text { ABSOLUTE } \\
\text { FREQUENCIES } \\
44 \\
\end{array}$} & \multirow{2}{*}{$\begin{array}{c}\text { PERCENTAGE \% } \\
37.9 \\
\end{array}$} & \multicolumn{2}{|c|}{$\begin{array}{c}\text { ABSOLUTE } \\
\text { FREQUENCIES }\end{array}$} & $\begin{array}{c}\text { PERCENTAGE } \\
\%\end{array}$ \\
\hline \multirow{2}{*}{$\begin{array}{l}\text { Gender of } \\
\text { responden } \\
\text { ts }\end{array}$} & Male & & & \multicolumn{2}{|c|}{21} & 19.8 \\
\hline & Female & 72 & 62.1 & \multicolumn{2}{|l|}{85} & 80.2 \\
\hline \multirow{6}{*}{$\begin{array}{l}\text { Age of } \\
\text { responden } \\
\text { ts (in } \\
\text { years) }\end{array}$} & $18-27$ & 69 & 59.5 & \multicolumn{2}{|l|}{10} & 9.4 \\
\hline & $28-37$ & 26 & 22.4 & \multicolumn{2}{|l|}{13} & 12.3 \\
\hline & $38-47$ & 11 & 9.5 & \multicolumn{2}{|l|}{8} & 7.5 \\
\hline & $48-57$ & 8 & 6.9 & \multicolumn{2}{|l|}{15} & 14.2 \\
\hline & $58-67$ & 2 & 1.7 & \multicolumn{2}{|l|}{20} & 19.9 \\
\hline & $\begin{array}{l}68 \text { and } \\
\text { more }\end{array}$ & - & - & \multicolumn{2}{|l|}{40} & 37.7 \\
\hline \multirow{5}{*}{$\begin{array}{l}\text { Level of } \\
\text { Education }\end{array}$} & $\begin{array}{l}\text { Elementary } \\
\text { school or } \\
\text { less }\end{array}$ & 1 & .9 & \multicolumn{2}{|l|}{-} & 160 \\
\hline & High School & 37 & 31.9 & \multicolumn{2}{|l|}{17} & 16.0 \\
\hline & $\begin{array}{l}\text { University } \\
\text { or college }\end{array}$ & 51 & 44.0 & 64 & & 60.4 \\
\hline & Master & 23 & 19.8 & 24 & & 22.6 \\
\hline & Doctorate & 4 & 3.4 & 1 & & .9 \\
\hline & $\begin{array}{l}\text { Up to EUR } \\
200\end{array}$ & 37 & 32.8 & Up to EUR 200 & 2 & 1.9 \\
\hline & $\begin{array}{l}\text { Between } \\
\text { EUR 200- } \\
300 \\
\end{array}$ & 15 & 12.9 & $\begin{array}{r}\text { Between EUR } \\
200-300\end{array}$ & 7 & 6.6 \\
\hline & $\begin{array}{l}\text { Between } \\
\text { EUR 300- } \\
400 \\
\end{array}$ & 23 & 19.0 & $\begin{array}{r}\text { Between EUR } \\
300-400\end{array}$ & 11 & 10.4 \\
\hline $\begin{array}{l}\text { Monthly } \\
\text { income }\end{array}$ & $\begin{array}{l}\text { Between } \\
\text { EUR 400- } \\
500 \\
\end{array}$ & 11 & 9.5 & $\begin{array}{r}\text { Between EUR } \\
400-500\end{array}$ & 12 & 11.3 \\
\hline & $\begin{array}{l}\text { Between } \\
\text { EUR 500- } \\
600\end{array}$ & 16 & 13.8 & $\begin{array}{r}\text { Between EUR } \\
500-600\end{array}$ & 19 & 17.9 \\
\hline & $\begin{array}{l}\text { Over EUR } \\
600\end{array}$ & 14 & 12.1 & Over EUR 600 & 55 & 51.9 \\
\hline Place of & City & 100 & 86.2 & 95 & & 89.6 \\
\hline residence & Village & 16 & 13.8 & 11 & & 10.4 \\
\hline Number & $1-2$ & 31 & 26.7 & 20 & & 19.8 \\
\hline of family & $3-4$ & 62 & 52.6 & 81 & & 75.5 \\
\hline members & 5 and more & 23 & 20.7 & 5 & & 4.7 \\
\hline & $\begin{array}{l}\text { Once per } \\
\text { year }\end{array}$ & 33 & 28.4 & 6 & & 5.7 \\
\hline & $\begin{array}{l}2-3 \text { times } \\
\text { per year }\end{array}$ & 44 & 37.9 & 27 & & 24.5 \\
\hline $\begin{array}{l}\text { Travels } \\
\text { per year }\end{array}$ & $\begin{array}{l}4 \text { and more } \\
\text { times per } \\
\text { year }\end{array}$ & 14 & 12.1 & 70 & & 67.0 \\
\hline & $\begin{array}{l}\text { I do not } \\
\text { travel every } \\
\text { year }\end{array}$ & 25 & 21.6 & 3 & & 2.8 \\
\hline $\begin{array}{l}\text { Average } \\
\text { annual }\end{array}$ & $\begin{array}{l}\text { Below EUR } \\
100\end{array}$ & 28 & 24.1 & $\begin{array}{r}\text { Below EUR } \\
100 \\
\end{array}$ & - & - \\
\hline $\begin{array}{l}\text { travel } \\
\text { spending }\end{array}$ & $\begin{array}{l}\text { EUR 100- } \\
200\end{array}$ & 17 & 14.7 & EUR 100-200 & 17 & 16.0 \\
\hline
\end{tabular}




\begin{tabular}{|c|c|c|c|c|c|c|}
\hline $\begin{array}{l}\text { of the } \\
\text { household }\end{array}$ & $\begin{array}{l}\text { Over EUR } \\
200\end{array}$ & 71 & 61.2 & $\begin{array}{r}\text { More than EUR } \\
200\end{array}$ & 89 & 84.0 \\
\hline \multirow{3}{*}{$\begin{array}{l}\text { How } \\
\text { many } \\
\text { times } \\
\text { services of } \\
\text { the travel } \\
\text { agency } \\
\text { last } \\
\text { travelled } \\
\text { with have } \\
\text { been used } \\
\text { so far? }\end{array}$} & Once & 76 & 65.5 & \multicolumn{2}{|l|}{22} & 20.8 \\
\hline & $\begin{array}{l}\text { Two or } \\
\text { three times }\end{array}$ & 30 & 25.9 & \multicolumn{2}{|l|}{55} & 51.9 \\
\hline & $\begin{array}{l}\text { Four or } \\
\text { more times }\end{array}$ & 10 & 8.6 & \multicolumn{2}{|l|}{29} & 27.4 \\
\hline
\end{tabular}

Source: Calculation by the authors

The answers to the questions and evaluations of the statements from the questionnaires were processed using the statistical software IBM SPSS 21. Kolmogorov - Smirnov test and Sapiro - Vilkov test was used to check the normality of the schedule. The distribution of the results of the continuous variables by gender and the place of residence is not normal, so Man-Vitney U test was used to test the auxiliary hypothesis. To test other auxiliary hypotheses (age and amount of monthly income), Kruskal-Volis test was used as non-parametric technique because the distribution of results was not normal.

\section{RESULTS OF RESEARCH AND DISCUSSION}

\subsection{Determining statistically significant differences in the loyalty of complainants relative to tourist service user gender}

The assumption about the normal distribution was not confirmed, and the determination of a statistically significant difference in the complainant's loyalty with respect to the gender was investigated using the Mann-Whitney $U$ test as a non-parametric alternative of the test of independent samples (Table 2). In order to consider the result of $Z$ approximation as statistically significant difference, the significance should be less than the required limit value of 0.05 .

Table 2: Statistics of test ${ }^{\mathrm{a}}$

\begin{tabular}{|c|c|c|}
\hline \multicolumn{2}{|l|}{ Country } & Loyalty of the complainant \\
\hline \multirow{4}{*}{ SERBIA } & Mann-Whitney U & 1482,5 \\
\hline & Wilcoxon W & 4110,5 \\
\hline & $\mathrm{Z}$ &,- 584 \\
\hline & Asymp. Sig. (2-tailed) & ,559 \\
\hline \multirow{4}{*}{ CROATIA } & Mann-Whitney U & 796,5 \\
\hline & Wilcoxon $\mathrm{W}$ & 1027,5 \\
\hline & $\mathrm{Z}$ &,- 771 \\
\hline & Asymp. Sig. (2-tailed) & ,441 \\
\hline
\end{tabular}

Source: Calculation by the authors 
Table 3: Mean value of rank and median

\begin{tabular}{|c|c|c|c|c|c|}
\hline Country & & Gender & $\mathrm{N}$ & Mean Rank & Median \\
\hline \multirow{3}{*}{ SERBIA } & \multirow{3}{*}{$\begin{array}{l}\text { Loyalty of the } \\
\text { complainant }\end{array}$} & Male & 44 & 60.81 & 4.0 \\
\hline & & Female & 72 & 57.09 & 3.6 \\
\hline & & Total & 116 & & \\
\hline \multirow{3}{*}{ CROATIA } & \multirow{3}{*}{$\begin{array}{l}\text { Loyalty of the } \\
\text { complainant }\end{array}$} & Male & 21 & 48.93 & 4.0 \\
\hline & & Female & 85 & 54.63 & 4.0 \\
\hline & & Total & 106 & & \\
\hline
\end{tabular}

Source: Calculation by the authors

The Mann-Whitney test did not reveal any statistically significant difference in loyalty between male $(\mathrm{Md}=4.0, \mathrm{n}=44)$ and female $(\mathrm{Md}=3.6, \mathrm{n}=72)$ in Serbia, $\mathrm{U}=1482.5, \mathrm{Z}=-0.584, \mathrm{p}=$ $0.559, \mathrm{r}=0.05$ (low impact). Male and female in Serbia are equally loyal to travel agencies.

The Mann-Whitney test did not reveal any statistically significant difference in loyalty of male $(\mathrm{Md}=4.0, \mathrm{n}=21)$ and female $(\mathrm{Md}=4.0, \mathrm{n}=85)$ in Croatia, $\mathrm{U}=796.5, \mathrm{Z}=-0.771, \mathrm{p}=0.441$, $\mathrm{r}=0.07$ (small effect). Male and female in Croatia are equally loyal to travel agencies.

The Mann-Whitney tests in Serbia and Croatia did not determine any statistically significant difference in the loyalty of complainants with regard to their gender, and it can be concluded that there is a statistically significant difference in the loyalty of complainants between tourist service users of the different gender; $\mathrm{H}_{1}$ : There is a statistically significant difference in the loyalty of the complainant between tourist service users of the of different gender, is not accepted.

The assumption about the normal distribution was not confirmed, and the determination of a statistically significant difference in the complainants' loyalty with respect to the age of the respondents was investigated using the Kruskal-Wallis test as a non-parametric alternative to a single-factor analysis of the variance of different groups (Table 4). If the value of the test is statistically significant, the results are converted into ranks, so mean ranges and median values are compared.

Table 4: Ranges

\begin{tabular}{|c|c|c|c|c|}
\hline Country & & Age of respondents & $\mathrm{N}$ & Mean Rank \\
\hline \multirow{6}{*}{ SERBIA } & \multirow{6}{*}{$\begin{array}{l}\text { Loyalty of } \\
\text { complainants }\end{array}$} & $18-27$ & 69 & 59.62 \\
\hline & & $28-37$ & 26 & 51.40 \\
\hline & & $38-47$ & 11 & 52.27 \\
\hline & & $48-57$ & 8 & 73.69 \\
\hline & & $58-67$ & 2 & 85.75 \\
\hline & & Total & 116 & \\
\hline \multirow{7}{*}{ CROATIA } & \multirow{7}{*}{$\begin{array}{l}\text { Loyalty of } \\
\text { complainants }\end{array}$} & $18-27$ & 10 & 39.25 \\
\hline & & $28-37$ & 13 & 44.88 \\
\hline & & $38-47$ & 8 & 47.25 \\
\hline & & $48-57$ & 15 & 40.63 \\
\hline & & $58-67$ & 20 & 57.33 \\
\hline & & 68 and more & 40 & \\
\hline & & Total & 106 & 64.03 \\
\hline
\end{tabular}

Source: Calculation by the authors 
Table 5: Statistics of the test ${ }^{\mathrm{a}, \mathrm{b}}$

\begin{tabular}{|c|c|c|}
\hline \multicolumn{2}{|l|}{ Country } & Loyalty of complainants \\
\hline \multirow{3}{*}{ SERBIA } & Chi-Square & 4,662 \\
\hline & $\mathrm{df}$ & 4 \\
\hline & Asymp. Sig. & ,324 \\
\hline \multirow{3}{*}{ CROATIA } & Chi-Square & 11,430 \\
\hline & $\mathrm{df}$ & 5 \\
\hline & Asymp. Sig. & 043 \\
\hline
\end{tabular}

Source: Calculation by the authors

The Kruskal-Wallis test did not disclose a statistically significant difference in the loyalty of complainants with regard to age of respondents in Serbia $(\mathrm{Gp} 1, \mathrm{n}=69: 18-27, \mathrm{Gp} 2, \mathrm{n}=26: 28$ $37, \mathrm{Gp} 3, \mathrm{n}=11: 38-47$ year, Gp4, $\mathrm{n}=8:$ :8-57 years, $\mathrm{Gp5}, \mathrm{n}=2: 58-67$ years $), \mathrm{c} 2(4, \mathrm{n}=116)$ $=4.662, \mathrm{p}=0.324$. Respondents of different age in Serbia are equally loyal to travel agencies. The Kruskal-Wallis test revealed a statistically significant difference in the loyalty of complainants with regards to age of the respondents in Croatia (Gp1, n =10: 18-27, Gp2, $\mathrm{n}=$ 13: 28-37, Gp3, $\mathrm{n}=8: 38-47 \mathrm{Gp} 4, \mathrm{n}=15: 48-57, \mathrm{Gp5}, \mathrm{n}=20: 58-67$ and $\mathrm{Gp} 6, \mathrm{n}=40: 68$ and older $), \mathrm{c} 2(5, \mathrm{n}=106)=11.430, \mathrm{p}=0.043$. Complainants' loyalty is highest among respondents aged 58-67 years (Mean Rank $=57.33, \mathrm{Md}=4.0)$, and the youngest respondents who are aged 18-27 (Mean Rank = 39.25, Md=3.7).

The Kruskal-Wallis tests in Serbia and Croatia did not reveal a statistically significant difference in the loyalty of complainants with regard to age of the respondents, hence it can be concluded that the hypothesis $\mathrm{H}_{2}$ : There is a statistically significant difference in the loyalty of complainants between tourist service users of the of different age, is not accepted.

The assumption about the normal distribution was not confirmed, and the determination of the statistically significant difference in the loyalty of complainants relative to the monthly income of the respondents was investigated using the Kruskal-Wallis test, as a non-parametric alternative to a single-factor analysis of the variance of different groups (Table 6). If the value of the test is statistically significant, the results are converted into ranks, so mean ranges and median values are compared.

Table 6: Ranges

\begin{tabular}{|c|c|c|c|c|}
\hline Country & & Monthly income of respondents & $\mathrm{N}$ & Mean Rank \\
\hline \multirow{7}{*}{ SERBIA } & \multirow{7}{*}{$\begin{array}{l}\text { Loyalty of } \\
\text { complainants }\end{array}$} & Up to EUR 200 & 37 & 62.92 \\
\hline & & EUR 200-300 & 15 & 70.23 \\
\hline & & EUR 300-400 & 23 & 64.28 \\
\hline & & EUR 400-500 & 11 & 42.77 \\
\hline & & EUR 500-600 & 16 & 51.94 \\
\hline & & Over EUR 600 & 14 & 44.61 \\
\hline & & Total & 116 & \\
\hline \multirow{7}{*}{ CROATIA } & \multirow{7}{*}{$\begin{array}{l}\text { Loyalty of } \\
\text { complainants }\end{array}$} & Up to EUR 200 & 2 & 74.50 \\
\hline & & \begin{tabular}{|l|} 
EUR 200-300 \\
\end{tabular} & 7 & 36.64 \\
\hline & & EUR 300-400 & 11 & 48.32 \\
\hline & & EUR 400-500 & 12 & 32.71 \\
\hline & & EUR 500-600 & 19 & 54.24 \\
\hline & & Over EUR 600 & 55 & 60.20 \\
\hline & & Total & 106 & \\
\hline
\end{tabular}

Source: Calculation by the authors 
Table 7: Statistics of the test ${ }^{\mathrm{a}, \mathrm{b}}$

\begin{tabular}{|c|c|c|}
\hline \multicolumn{2}{|l|}{ Country } & Loyalty of complainants \\
\hline \multirow{3}{*}{ SERBIA } & Chi-Square & 8,748 \\
\hline & $\mathrm{df}$ & 5 \\
\hline & Asymp. Sig. &, 120 \\
\hline \multirow{3}{*}{ CROATIA } & Chi-Square & 11,776 \\
\hline & df & 5 \\
\hline & Asymp. Sig. & 038 \\
\hline
\end{tabular}

Source: Calculation by the authors

The Kruskal-Wallis test did not disclose a statistically significant difference in the loyalty of complainants with regard to the amount of monthly income of respondents in Serbia $(\mathrm{Gp} 1, \mathrm{n}=$ 37: up to EUR 200, Gp2, n = 15: EUR 200-300, Gp3, $n=23$ : EUR 300-400, Gp4, $n=11$ : EUR 400-500, Gp5, $\mathrm{n}=16$ : EUR 500-600, Gp6, $\mathrm{n}=14$ : over EUR 600), c2 (5, $\mathrm{n}=116)=8,748, \mathrm{p}$ $=0.120$. Respondents with varying levels of monthly income in Serbia are equally loyal to travel agencies.

The Kruskal-Wallis test revealed a statistically significant difference in the loyalty of complainants with regard to the amount of monthly income of respondents in Croatia (Gp1, $\mathrm{n}$ = 2: up to EUR 200, Gp2, n = 7: EUR 200-300, Gp3, $\mathrm{n}=11$ : EUR 300-400, Gp4, $\mathrm{n}=12$ : EUR 400-500, Gp5, $\mathrm{n}=19$ : EUR 500-600, Gp6, $\mathrm{n}=55$ : over EUR 600), c2 (5, n = 106) = 11,776, $\mathrm{p}$ $=0.038$. The loyalty of complainants is highest among respondents with monthly income up to EUR 200 (Mean Rank =74.50, Md = 4.3), and the smallest among respondents with monthly income between EUR 400 and 500 (Mean Rank=32.71, Md=3.4).

The Kruskal-Wallis test in Serbia did not reveal while in Croatia it revealed a statistically significant difference in the loyalty of complainants with regard to monthly income of the respondents, hence, it can be concluded that the hypothesis $\mathrm{H}_{4}$ : There is a statistically significant difference in the loyalty of complainants among tourist services users of different amounts of monthly income, is partially accepted.

The assumption about the normal distribution was not confirmed, and the determination of the statistically significant difference in the complainants' loyalty with respect to the place of residence of the respondents was investigated using the Mann-Whitney $U$ test, as a nonparametric alternative of the t-test of independent samples (Table 8).

Table 8: Statistics of the test ${ }^{\text {a }}$

\begin{tabular}{|c|c|c|}
\hline \multicolumn{2}{|l|}{ Country } & Loyalty of the complainant \\
\hline \multirow{4}{*}{ SERBIA } & Mann-Whitney U & 675.5 \\
\hline & Wilcoxon $\mathrm{W}$ & 5725.5 \\
\hline & $\mathrm{Z}$ & -1.008 \\
\hline & Asymp. Sig. (2-tailed) & .313 \\
\hline \multirow{4}{*}{ CROATIA } & Mann-Whitney U & 283.5 \\
\hline & Wilcoxon W & 349.5 \\
\hline & $\mathrm{Z}$ & -2.510 \\
\hline & Asymp. Sig. (2-tailed) & .012 \\
\hline
\end{tabular}

Source: Calculation by the authors 
Table 9: Mean value of rank and median

\begin{tabular}{|l|l|c|c|c|c|}
\hline \multicolumn{2}{|c|}{ Country } & Place of living & $\mathrm{N}$ & Mean Rank & Median \\
\hline \multirow{3}{*}{ SERBIA } & \multirow{2}{*}{$\begin{array}{l}\text { Loyalty of the } \\
\text { complainant }\end{array}$} & City & 100 & 57.26 & 3.6 \\
\cline { 3 - 5 } & & Village & 16 & 66.28 & 4.1 \\
\cline { 3 - 6 } & \multirow{3}{*}{ CROATIA } & Total & 116 & & \\
\cline { 3 - 6 } & \multirow{2}{*}{\begin{tabular}{l} 
Loyalty of the \\
\cline { 3 - 5 }
\end{tabular}} & City & 95 & 56.02 & 3.0 \\
\cline { 3 - 6 } & & Village & 11 & 31.77 & 3.6 \\
\cline { 3 - 6 } & & Total & 106 & & \\
\hline
\end{tabular}

Source: Calculation by the authors

The Mann-Whitney test did not reveal a statistically significant difference in the loyalty of the respondents residing in cities $(\mathrm{Md}=3.6, \mathrm{n}=100)$ and villages $(\mathrm{Md}=4.1, \mathrm{n}=16)$ in Serbia, $\mathrm{U}$ $=675.0, \mathrm{Z}=-1,008, \mathrm{p}=0.313, \mathrm{r}=0.09$ (a small influence). Respondents from the city and villages in Serbia are equally loyal to travel agencies.

The Mann-Whitney test revealed a statistically significant difference in the loyalty of respondents residing in cities $(\mathrm{Md}=4.0, \mathrm{n}=95)$ and villages $(\mathrm{Md}=3.6, \mathrm{n}=11)$ in Croatia, $\mathrm{U}$ $=283.5, Z=-2.510, p=0.012, r=0.24$ (small to medium influence). Loyalty to travel agencies is higher among respondents from cities compared to respondents from villages.

Bearing in mind that the Mann - Whitney U test in Serbia did not disclose a statistically significant difference in the loyalty of complainants with regard to the place of respondents' residence, while in Croatia it did reveal a statistically significant difference, it can be concluded that the established hypothesis $\mathrm{H}_{5}$ : There is a statistically significant difference in the loyalty of complainants between tourist service users with different place of residence, is partially accepted.

After examining statistically significant differences in the loyalty of the complainant relative to the individual socio-demographic characteristics of the respondents (i.e. tourist service users) through four individual hypotheses:

$\mathrm{H}_{1}$ : There is a statistically significant difference in the loyalty of complainants between tourist service users of different gender - it is not accepted;

$\mathrm{H}_{2}$ : There is a statistically significant difference in the loyalty of complainants between tourist services users of different age - it is not accepted;

$\mathrm{H}_{3}$ : There is a statistically significant difference in the loyalty of complainants between tourist services users of different amounts of monthly income - it is partially accepted;

$\mathrm{H}_{4}$ : There is a statistically significant difference in the loyalty of complainants between the tourist service users of the with a different place of residence - it is partially accepted;

it can be concluded that the above assumption $\mathrm{H}_{0}$ : There is a statistically significant difference in the loyalty of complainants between tourist service users of various socio-demographic characteristics, is partially accepted.

\section{CONCLUSION}

The results of the conducted research partially confirmed the existence of a statistically significant difference in the loyalty of complainants among users of different sociodemographic characteristics. Respondents from Serbia of different gender, age, income level and place of residence are equally loyal to travel agencies. Male and female in Croatia are 
equally loyal to travel agencies. The results of the study also showed that among the respondents from Croatia the loyalty of complainants was at the highest level among the respondents aged 58-67, and the smallest among the respondents aged 18-27. Among the respondents from Croatia the highest level of loyalty is among respondents with monthly income up to EUR 200, and the smallest among respondents with monthly income between EUR 400 and 500. Loyalty to tourist agencies is higher among respondents residing in cities in Croatia compared to the respondents from the village.

The results of certain research conducted in travel agencies have shown that a negligible number of satisfied users would contact the agency after the trip, to thank and congratulate them on good organization [8]. Some travel agencies have a policy to contact their former users at least six times a year. When users only contact the travel agency on their own initiative only when they are dissatisfied and use this occasion to give reasons for their dissatisfaction, then this should be used as an opportunity to maintain user relations. Submission of a complaint by an unsatisfied user and afterwards a service recovery can be used to retain dissatisfied users and to build better and longer-term relationships. Gathering information about dissatisfied users provides travel agencies with the opportunity to launch a recovery service. Creating a database with user profiles can help agencies overcome inter-organizational communication problems. The advisory role of employees and personalized services for each user of a specific travel agency provides a wide range of alternative solutions and is only possible when information about service users is available.

Complaint behavior is a field of research that identifies all aspects involved in service failure. The identified partial acceptance of the main hypothesis is sufficient to show that the influence of certain socio-demographic characteristics upon the loyalty of complainants is affected. After conducting the research, certain questions that may serve as the starting point for future research arise. In addition to examining the impact of the socio-demographic characteristics of the complainant, new research can be based on determining the impact of psychographic factors on the loyalty of the complainant.

In modern, competitive conditions based on a struggle to retain each user, it is necessary to improve employee sales techniques, strengthen customer relations and encourage their engagement in communication with the travel agency. When users are dissatisfied, actions taken by the travel agency must be faster and directed towards the right users. Dissemination of customer information and building relationships based on mutual trust is an adequate basis for achieving high turnover with adequate profitability and consistent levels of loyalty.

\section{REFERENCES}

[1] Stanić - Jovanović, S. (2016) Značaj poslovanja turističkih agencija u ekonomiji turističkog sektora današnjice: Studija slučaja Srbije. International thematic monograph Thematic proceedings - Beograd, pp. 627.

[2] Yi, Y., Nataraajan, R., Gong, T. (2011) Customer participation and citizenship behavioral influences on employer performance, satisfaction, commitment and turnover intention. Journal of Business Research, 64, pp. 88.

[3] Alvarez, L. S., Casielles, R. V., Martín, A. M. D. (2010) Analysis of the role of complaint management in the context of relationship marketing. Journal of Marketing Management, 27(1-2), pp. 143. 
[4] Aqviar - Quintana, T., Moreno - Gie, S., Picazo - Peral, P. (2016) How could traditional agencies improve their competitiveness and survive? A qualitative study in Spain. Tourism Management Perspectives, 20, pp. 100.

[5] Senić, R., Senić, V. (2013) Sprečavanje odlaska postojećih i pospešivanje povratka izgubljenih kupaca. Marketing, 41 (4), 335.

[6] McQuilken, L., Robertson, N. (2011) The influence of quarantees, active requests to voice and failure severity on customer complaint behavior. International Journal of Hospitality Management, 30 (4), pp. 955.

[7] Eccles, G., Durand, P. (1998) Complaining customers, service recovery and continuous improvement. Managing Service Quality: An International Journal, 8(1), pp. 68-69.

[8] Mišković, I. (2012) Ethics in Providing Tourism Services by travel Agents in Serbia. Turizam, 16 (1), pp. 26-27.

[9] Homburg, C., Fürst, A., Koschate, N. (2010) On the importance of complaint handling design: a multi-level analysis of the impact in specific complaint situations. Journal of the Academic Marketing Science, 38, pp. 265-269.

[10] Choraria, S. (2013) Exploring the Role of Negative Emotions on Customer's Intention to Complain. Vision, 17 (3), pp. 201.

[11] Metehan, T., Yasemin, Z. A. (2011) Demographic Characteristic and Complaint Behavior: An Empirical Study Concerning Turkish Customers. International Journal of Business and Social Science, 2(9), pp. 44-45.

[12] Heung, V. C. S., Lam, T. (2003) Customer complaint behavior towards hotel restaurant services. International Journal of Contemporary Hospitality Management, 15 (5), pp. 286288.

[13] Reynolds, K. L., Harris, L. C. (2005) When service failure is not service failure: an exploration of the forms and motives of ,illegitimate" customer complaining. Journal of Services Marketing, 19 (5), pp. 322.

[14] Tronvoll, B. (2007) Complainer characteristics when exit is closed. International Journal of Service Industry Management, 18(1), pp. 33.

[15] Phau, I., Baird, M. (2008) Complainers versus non-complainers retaliatory responses towards service dissatisfactions. Marketing Intelligence \& Planning, 26(6), pp. 593-594. 